\title{
ПОНЯТТЯ КУЛЬТУРИ В ПЕРЕКЛАДІ ТА ПЕРЕКЛАДОЗНАВСТВІ: ДО ПИТАННЯ ВИЗНАЧЕННЯ
}

\section{Тетяна Ляшенко}

\author{
Львівський національний університет імені Івана Франка, \\ вул. Університетська, 1, м. Львів, Україна, 79000 \\ laschenko_t@yahoo.de
}

\begin{abstract}
У статті запропоновано перекладознавче визначення поняття культури, релевантне для художнього перекладу як культурологічного явища. Проаналізовано різні підходи до розуміння культури в перекладознавстві, німецькомовному зокрема. Увагу зосереджено на перевагах та недоліках поширених тлумачень культури для перекладознавчих досліджень. Розглянуто питання змістовного і просторового визначення поняття культури. Охарактеризовано розуміння культури в процесі міжкультурної комунікації і роль художнього перекладу в ньому. 3'ясовано особливості відображення культури в художньому тексті. Запропоновано шляхи розв'язання проблеми ідентифікації і перекладу культурної інформації в художньому перекладі. Окреслено перспективи подальших досліджень, які полягають в операціоналізації поняття культури на емпіричному рівні, системному описі проявів культури у вихідному тексті і системному підході до відтворення культурної інформації в тексті перекладу.

Ключові слова: культура, перекладознавство, міжкультурна комунікація, художній переклад, художній текст.
\end{abstract}

Вступ. Починаючи з 80-х років минулого століття, перекладознавці тлумачать переклад як міжкультурний процес [16], говорять про переклад як міжкультурне явище (cross-cultural event) [17], описують його як міжкультурний трансфер [18] та як свідомий обмін культурними цінностями між народами, який збагачує не лише цільову літературу, а й загальну скарбницю світової літератури [4]. Вихідним положенням сучасного перекладознавства $є$ визнання комунікативної сутності тексту, тобто тексту зануреного в комунікативну ситуацію, яку визначає соціокультурний контекст.

Отже, поняття культури стає одним 3 ключових у перекладознавстві. Загальноприйняті визначення складного та полісистемного явища культури є розмитими і нечіткими. Окреслення розуміння поняття культури в перекладознавстві ускладнює також наявність численних визначень цього феномену в окремих галузях науки. Більшість дефініцій культури наголошують на іiї семіотичній природі, системності, цілісності, комплексності, структурності, наявності ціннісної домінанти, нормативності, надсуб'єктності, можливості іiі множинних інтерпретацій. У перекладознавстві, попри беззаперечне визнання вагомості феномену культури для перекладу, це поняття зазвичай використовують на основі інтуїтивного розуміння, не витлумачуючи його, або послуговуються дефініціями інших суспільних наук. Необхідність перекладознавчого визначення поняття культури зумовлює актуальність цієї розвідки.

(C) Ляшенко Т., 2021 
Аналіз останніх досліджень і публікацій. Питання тлумачення поняття культури в німецькомовному просторі ставало предметом розгляду низки науковців. Зокрема, окреслено нові орієнтири в науках про культуру [10]; здійснено спробу з'ясувати значення поняття культури і культурології для перекладознавства і практики перекладу [9]; подано критичний огляд підходів до феномену культури, охарактеризовано найрепрезентативніші дефініції цього поняття в перекладознавчій літературі [12]; у межах транскультурної комунікації виокремлено два концептуальних підходи до поняття культури [11]. Вукраїнськомовних перекладознавчих дослідженнях розглянуто питання взаємозв'язку та взаємодії культури та перекладу [4]; проаналізовано проблему місця і ролі поняття "культура" в теорії і практиці перекладу [7]; у межах культуроцентричного підходу розглянуто культуру як оперативну одиницю перекладу із вербальним втіленням [5], а також окреслено зв'язок перекладу із процесами націєтворення з опорою на методологію “культурного повороту” [1]. Незважаючи на той факт, що за останні десятиліття культурологічний підхід став засадничим для лінгвістичних і перекладознавчих студій, ще досі не напрацьовано послідовну і чітку культурологічну перекладацьку концепцію. Саме поняття "культура" попри широке використання в перекладознавстві також потребує диференційованого визначення, зокрема у культурологічній моделі художнього перекладу, що становить мету цього дослідження. Беручи до уваги міждисциплінарний характер перекладознавства i сутність перекладу як міжкультурної комунікації, у своїй гіпотезі припускаємо, що перекладознавче визначення поняття культури поєднує головні аспекти його розуміння в культурології, соціально-культурній антропології і міжкультурній комунікації; воно дає змогу окреслити культурні фонові знання перекладача, необхідні з одного боку для розуміння тексту, а з іншого, для адекватного перекладу культурної інформації.

Методологія дослідження. Із початком методологічних змін наприкінці 80-х років XX ст., які отримали назву культурного повороту (Cultural Turns), традиційне розуміння культури починають протиставляти новим концепціям. Плюралізм таких концепцій, методів і аналітичних категорій демонструє німецька літературознавиця і культурологиня Д. Бахманн-Медік у роботі “Культурні повороти. Нові орієнтири в науках про культуру”. Дослідниця веде мову про сім культурних поворотів у науках про культуру, кожен з яких має своє бачення цього поняття. У межах інтерпретативного або семіотичного підходу до культури цей феномен визначають як цілісну системну організацію текстів, які мають знакову і символічну сутність. Крізь метафору тексту Ю. Лотмана культуру слід сприймати як ансамбль текстів, як систему смислів i значень у іï багатошаровості прочитання, що в залежності від контексту призводить до множинних інтерпретацій культурних значень [10, с. 72]. Рефдексивний, також літературний поворот, висуває на передній план проблему культурної репрезентації і залежності опису чужих культур від влади. У межах цього повороту формується нове розуміння культури не як здатного до об'єктивації, цілісного резервуара символів i смислів, а як динамічного взаємозв'язку комунікативних практик і репрезентацій $[10$, c. 169], тобто як складної динамічної системи (поведінки, норм, цінностей та ін.), яка може змінюватися відповідно до соціальної ситуації. Перформативний поворот модифікує поняття культури і тлумачить його як перформанс, як відкритий 
і динамічний процес, який можна розкрити за допомогою словника дій (способів візуалізації) і медіальних інсценувань [10, с. 107]. Цей поворот спрямований на розуміння прагматичного процесу символізації шляхом аналізу символів в історичному контексті їх використання, у їхньому зв'язку з такими процесуальними формами як ритуал і соціальна драма [10, с. 113]. Постколоніальний поворот у науках про культуру спричинив “критику канону”, а також критичне переосмислення центрального поняття культури “культурна ідентичність”. У межах цього повороту розвинулося також критичне ставлення до понять “репрезентація" і “гегемонія” в постколоніальному просторі міжнародних владних структур. Тенденцію до деспатіалізації культури демонструє просторовий поворот, який виводить на передній план проблеми локалізації культури (Хомі Баба), простір стає аналітичною категорією, принципом вибудови соціальної поведінки, а також ефективною стратегією репрезентації [10, c. 291-293]. Іконічний (пікторіальний) поворот висунув вимогу по-новому дивитися на пізнавальну сутність зображень, розуміти не лише образи, а й світ через образи. Представники цього повороту виступають проти панівної ролі мови, мовної системи і логоцентризму західної культури [10, с. 329].

Зосередимо увагу докладніше на перекладацькому повороті, оскільки внаслідок глобалізації зав'язків світового співтовариства він займає активні позиції в науках про культуру і суспільство. Переклад виходить за межі лінгвістично-текстуальної парадигми, переростає рівень предметності і стає аналітичною категорією. 3 1980-х років перекладознавство перетворюється на культурологічне дослідження перекладу, спрямоване на переклад культур і переклад між культурами (kulturelle Übersetzung). Саме поняття переклад тлумачать ширше як трансфер чужих способів мислення, картин світу і соціальних практик [16], відповідно, в перекладачах вбачають посередників між мовами і культурами. Тексти розглядають відповідно до контексту їхнього творення і ситуації функціонування. Класичні, орієнтовані на текст, категорії художнього перекладу доповнюються новими, такими як культурна репрезентація і трансформація, чужість і несхожість, культурні розбіжності і влада. Відбувається і перекладащьке переосмислення культури, яку розуміють як процес перекладу “культура як переклад”. Перекладний характер культур вбачають у їх багатошаровості, гібридності як активного простору перекладацьких процесів [10, с. 248].

Проаналізувавши різні концепції щодо розуміння культури і традиції іiі дослідження, вважаємо перспективним для перекладознавства поєднання лінгвістичного, інтерпретативного та перекладацького поворотів. Інтегративний підхід дозволяє розглядати переклад як багатоаспектну складну діяльність, у якій нової інтерпретації набуває взаємозв'язок мови і культури, а також роль перекладача. Підтримуємо думку Д. Бахманн-Медік щодо стрижневого характеру для всіх інших парадигм лінгвістичного повороту, оскільки він наголошує на тісному зв'язку мови та культури. Семіотичне тлумачення культури та метафора “культура як текст", започатковані лінгвістичним поворотом, дістають подальший розвиток у межах інтерпретативного повороту. Завдяки К. Гірцу відбувся поворот до інтерпретативної культурної антропології і водночас від традиційного розуміння культури як “усього способу життя” до ііі тлумачення як системи знаків і символів [10, с. 37]. 
Семіотичний підхід призводить до критичного переосмислення не лише поняття культури, а й уводить до наукового вжитку широке поняття тексту як зафіксованої діiі. Ситуації, в яких відбуваються дії, можна "прочитати", тобто протлумачити як письмові тексти. Таке широке розуміння тексту уможливлює його застосування до таких форм виразності як ритуали, твори мистецтва, святкування та інше і слугує основою поняття культури як ансамблю текстів. Розуміння культури як тексту означає визнання культурної функції літератури як засобу не лише оформлення смислу, а й його породження, і конструювання таким чином дійсності. У межах перекладацького повороту поняття перекладу виводиться за межі лише мовного перекладу текстів. Переклад тлумачать як міжкультурний трансфер, а в цьому процесі водночас і трансфер мовний. Перекладачеві відводиться роль експерта 3 прочитання складної системи смислів і значень вихідної культури і культури перекладу.

Погоджуємося 3 думкою дослідника Г. Флорос про релевантність для перекладознавства визначень поняття культури в таких галузях наук, які передбачають застосування або теоретичне обгрунтування міжкультурного порівняння, $\mathrm{i}$ для яких культура $\epsilon$ предметом, а не засобом дослідження. Зокрема мова йде про культурну антропологію, культурологію, семіотику культури, міжкультурну комунікацію, германістику, компаративістику і соціологію [12, с. 9-10], оскільки ці науки виявляють тісний зв'язок між собою щодо питання окреслення поняття культури.

Результати дослідження та їхнс обгрунтування. Німецькомовні перекладознавчі дослідження 70-х років XX століття ще не приділяли належної уваги культурному виміру в теорії перекладу. В. Коллер розглядав культуру лише як один з низки важливих чинників, які слід брати до уваги в підході до перекладу, орієнтованому на мову, текст і комунікацію [14, с. 122]. На думку науковця, оперувати загальним поняттям культури в перекладознавстві надто складно, тому слід вести мову про “культуру перекладу” (курсив мій. - Т. Л.), яка дозволятиме долати культурні бар'єри та уможливить шанобливий доступ до “чужого" [14, с. 129]. Отже, перекладознавець тлумачить поняття культури як складову міжкультурного діалогу, завдяки якій наголошується розмаїття культур.

Спроби абстрактного визначення поняття культури в теорії перекладу критикує також Г. Флорос, оскільки такий підхід не дає змоги розпізнати прояви культури в тексті $[12$, с. 27-28]. Науковець обстоює думку, що здатність виявити культурну інформацію в тексті є передумовою здійснення перекладу.

Мудерсбах К., вказуючи на взаємозв'язок між культурою і перекладом, зазначає, що кожна спільнота й окремий ії представник потребують не лише власну, а принаймні одну контрастну/“чужу” культуру для усвідомлення відносного характеру очевидного в своїй культурі та уникнення абсолютизації іï елементів [15, с. 188]. Роль перекладача дослідник вбачає у відповідальному посередництві між обома культурами, можливому за умови усвідомлення відмінностей між ними [15, с. 189]. Цією тезою К. Мудерсбах наголошує на міжкультурному аспекті перекладу як взаємодії різних культур.

Гьорінг Г., розвиваючи дефініцію культури американського антрополога В. Гудинафа, пристосовує іiі до завдань перекладача і визначає культуру як "все те, що перекладач має знати і відчувати з огляду на суспільство вихідної мови та мови 
перекладу”. Таке розуміння культури, на думку науковця, дає змогу перекладачеві оцінити прийнятність моделей поведінки й очікування суспільства, самому відповідно до них діяти і сприймати світ (і тексти) як ії̈ представник [13, с. 112]. 3 огляду на це, дефініція Г. Гьорінга є провідною для функціональної моделі перекладу.

Німецький мовознавець Й. Альбрехт здійснив спробу з'ясувати значення культури і культурології для перекладознавства і практики перекладу. Науковець порівнює два визначення поняття культури, а саме дефініцію, наведену в багатотомній німецькій універсальній енциклопедії Брокгауз, і визначення Г. Гьорінга, на яке покликається більшість німецьких перекладознавців. Перше загальне визначення певною мірою перегукується із тлумаченням культури італійського філософа Джамбатісти Віко, яке протиставляє світу природних об'єктів і явищ світ створених людством артефактів: "У широкому вжитку поняття культура може означати все, що людина створила, тобто що не дане природою. У вужчому розумінні поняття “культура" означає сфери діяльності, в яких людина здатна створювати на тривалу перспективу артефакти, форми виробництва, форми соціальної поведінки та базові принципи, які формують чи репрезентують зв'язки на індивідуальному чи колективному рівнях та можуть в подальшому через систему цінностей або всі інші форми і вияви керувати подальшою діяльністю або структурувати їі” (переклад мій. -Т. Л.) [9, с. 74].

Орієнтоване на перекладача та його цілі визначення поняття культури Г. Гьорінга, на думку Й. Альбрехта, акцентує увагу на культурній специфіці рольових очікувань суспільства [9, с. 74], тобто закріплених у системі соціальних норм вимог до поведінки індивіда під час виконання певної соціальної ролі.

У транскультурній комунікації, на думку 3. Денгшерц, важливо розрізняти щонайменше два виміри поняття культури: змістовний i екстенсіональний (просторовий), на що свого часу вказував німецький філософ, представник постмодернізму Вольфганг Вельш. У межах змістовного виміру відбувається осмислення сутності культури - що є культура і що до неї належить. У межах екстенсіонального виміру науковці шукають відповідь на питання, хто репрезентує певну культуру, кого можна до неї віднести і де вона поширена. Обидва виміри не завжди чітко розрізняють. У побутовій мові культуру співвідносять з певною нацією, релігією, певним регіоном або етносом, тобто домінує екстенсіональне розуміння культури [11, с. 232].

Зумовлене культурними поворотами критичне переосмислення поняття культури на змістовному рівні призвело до розширення цього поняття. До культури почали відносити не лише “високу культуру”, а також “мову і текст як формотвірні і рушійні сили соціальної дії” [11, с. 13]. Таке розширене тлумачення культури на рівні змістовному, на думку 3. Денгшерц, загрожує узагальненням та есенціалізацією визначень культури, якщо не відбуватиметься переосмислення культури на рівні екстенсіональному.

Певною протидією зазначеним небезпекам стають підходи, спрямовані проти есенціалістських визначень сутності культури як замкненої в собі й однозначної ідентичності. Уявлення про колективну ідентичність стосуються не лише поняття гомогенності, а й поняття гетерогенності. Визначення екстенсіонального виміру 
культури у перекладознавстві становить певні труднощі, оскільки його часто тлумачать як змінну величину. Колективи, комунікативні спільноти, групи адресатів у комунікативній ситуації перекладу можуть охоплювати різні рівні, зокрема національний чи соціальний. 3. Денгшерц зауважує, що “національна культура" як категорія ще не повністю вичерпала себе, проте у більшості комунікативних ситуацій застосування цієї категорії стає надто поверхневим, оскільки тоді не беруться до уваги колективні зв'язки, які суттєво впливають на комунікативну ситуацію [11, с. 234]. Термін “соціокультура", як зазначає Ф. Пьохгакер, також не вирішує проблему, оскільки постає питання його наповнення. Перекладознавець вказує на необхідність подальших досліджень в галузі соціології або порівняльної культурології, обстоюючи таким чином міждисциплінарний погляд на вказану проблематику [11, с. 234-235].

Головним питанням щодо проблеми змістовного окреслення поняття культури $\epsilon$ співвідношення загального/універсального і специфічного. Універсальне присутнє в змісті кожної окремої культури, наприклад, як універсальні структури свідомості (Е. Гуссерль), як психологічна єдність людства (К. Юнг), як основа культури земного соціуму, щодо якої всі іiї різновиди лише окремі прояви (шифри) (М. Хайдеггер, К. Ясперс) [8, с. 19]. Оскільки культура є загальнолюдським феноменом, національні культури збігаються в певних елементах, а споріднені в багатьох. Водночас все, що людина створює для людини, має відмінності відносно місця і часу, епохи і цивілізації, а також численних конкретних умов. Такі відмінні елементи становлять інтерес перекладача, оскільки стають бар'єром для розуміння й ефективної комунікації. Універсальні елементи національних культур навпаки $є$ передумовою успішної міжкультурної комунікації.

У структурі культури, на думку перекладознавиці Н. Тимко, можна виокремити три складові, кожна з яких має надіндивідуальну природу: матеріальну, духовну, а також інтеракиійну. Інтеракційну складову становить сукупність способів організації взаємодії 3 метою продукування матеріального i/aбо духовного. Доцільність виокремлення інтеракційної складової культури зумовлена, по-перше, діяльнісною природою всього культурного середовища: усі культурні артефакти і феномени є результатом певного виду/типу/роду/аспекту діяльності [8, с. 13]. По-друге, якщо в духовній складовій багато культур можуть бути близькими, то в інтеракційній складовій ці культури можуть демонструвати вагомі відмінності (для порівняння культури ФРН і Австрії). Цей факт зумовлює необхідність виявляти культурну специфіку не лише в матеріальному i/aбо духовному, а й в інтеракційному, тобто у способах організації спільної діяльності людей для досягнення певної мети.

Отже, культура є об’ємним за змістом і смислом, цілісним явищем, яке відносить людей, що населяють певний простір, до певної спільноти-народу, нації. Під простором Н. Тимко пропонує розуміти не певну географічну територію, а насамперед простір культурного середовища з параметрами не лише протяжності, а й глибини [8, с. 14]. Вважаємо, що для перекладознавчого визначення культури релевантною спільнотою, яку охоплює простір культурного середовища, є спільнота лінгвокультурна як єдність народу, його мови і культури. 
Важливим аспектом є розуміння культури в процесі міжкультурної комунікації і роль перекладу в ньому. У наш час глобалізованого мультикультурного сучасного світу міжкультурна комунікація, опираючись на спільні універсальні цінності, $\epsilon$ способом конструктивної і безконфліктної взаємодії різних етнічностей і різних культур. 3 огляду на цей факт, актуальним стає визначення культури В. Маслової, в якому наголошується вагомість міжкультурного діалогу для існування культури та іiі поступу: 'Культура - це сукупність усіх форм діяльності суб'єкта в світі, заснована на системі установок і приписів, цінностей і норм, зразків і ідеалів, це спадкова пам'ять колективу, яка “живе” лише в діалозі з іншими культурами” [8, с. 294].

Проблеми діалогу культур дозволяє вирішувати переклад шляхом урахування культурних особливостей лінгвокультурних спільнот і нейтралізації культурних бар'єрів в процесі двомовної опосередкованої комунікації. Визнання впливу культурних фактів на процес перекладу не повинно проте призводити до гіпостазування ролі культурних відмінностей. Заміна лінгвістичного підходу до перекладу на суто культурологічний підхід (“перекладають не мови, а культури”), на нашу думку, є невиправданим, оскільки спрощує набагато складнішу дійсність: культурні відмінності знаходять відображення в мові, стаючи частиною відмінностей в картинах світу, які творять мови.

Теоретики текстологічної теорії $[2 ; 3 ; 6]$ розглядають художній текст як віддзеркалення тексту культури, тобто складної, ієрархічно організованої системи, у межах якої відбувається взаємодія різних текстів та семіотичного середовища. Художній текст у плані культурному $є$ своєрідним явищем, оскільки він описує особливу дійсність, яку творить автор тексту. Особливий світ тексту можна віднести до певної культури, враховуючи певні “ключи” тобто маркери, які автор розставляє в тексті. Це можуть бути очевидні посилання на певні культури за допомогою експліцитних засобів, або імпліцитні вказівки на дії, вчинки, специфічні риси, які зазвичай асоціюють $з$ моделями певної культури.

Усю культурну інформацію в художньому тексті можна поділити на дві групи: культура в мові і культура, описувана мовою. У першому випадку йдеться про особливу мовну картину світу, тобто особливості культури, що зафіксовані в мові в якості національно-специфічних одиниць (реалій та ін.), різнопланових конотацій значення мовних одиниць. У другому випадку йдеться про представлені автором в змісті тексту об’єкти національної матеріальної і духовної культури як позамовної реальності. Отже, елементами культури, які становлять проблеми перекладу, є і екстралінгвістичні поняття, тобто явища і події, що мають місце у певній лінгвокультурній спільноті, i “культурно зумовлені” одиниці мови як маркери певної культури.

У науково-методичних підходах, орієнтованих на переклад культури в текстах, ще досі не вдалося вирішити суперечність між поглядами, які спрямовують увагу на окремі елементи культури в тексті на рівні мікроструктурному, і поглядами, які прагнуть до цілісного розгляду культури в тексті на рівні макроструктурному. На мікроструктурному рівні елементи культури в тексті розпізнають і перекладають фрагментарно. Протилежний цілісний підхід до перекладу елементів культури в тексті залишається, на думку Г. Флорос, переважно інтуїтивним рішенням перекладача [12, c. 50]. 
Для розв'язання зазначеної проблеми вважаємо доцільним системний опис культури в художніх текстах, щоби уможливити іiі ідентифікацію на макро- та мікроструктурному рівнях. Оскільки наявні методи перекладу елементів культури в текстах є насамперед проспективними, орієнтованими на фазу реалізації повідомлення мовою перекладу, пропонуємо розглядати питання ідентифікації та перекладу культурної інформації також на етапах декодування вихідного тексту та його перекодування.

У ситуації перекладу ні автор тексту оригіналу, ні читач тексту перекладу не мають змоги перевірити, наскільки елементи культури, відтворені у перекладі, відповідають дійсності. У такому випадку вся відповідальність лягає на плечі перекладача як експерта в обох культурах. 3 одного боку, перекладач має бути лояльним до автора оригіналу і прагнути зберегти його культурні маркери. 3 іншого, він має полегшити читачеві перекладу їх сприйняття. Здійснюючи переклад елементів культури, перекладач стоїть перед вибором збереження конвенцій вихідної культури чи їх заміни на конвенції культури перекладу. Вибір перекладацької стратегії зумовлює вага культурної інформації в системі цінностей, представлених в тексті оригіналу.

Для побудови культурологічної моделі перекладу, яка враховує відображення культури в художньому тексті і пропонує механізми ії перекладу, важливо випрацювати перекладознавчу дефініцію поняття культури. Аналіз різних підходів до окреслення поняття культури і релевантних для перекладу аспектів його дослідження дозволив запропонувати таке визначення:

Культура - це складна, ієрархічно організована система матеріальних, духовних і соиіальних цінностей певної лінгвокультурної і/або соџіокультурної спільноти, які у зіставленні з иінностями інших спільнот виражають особливості ї̈ світобачення, суспільного і повсякденного життя. Культура знаходить своє відображення в мові і тексті як особлива мовна картина світу й об'єкт опису. Вона продовжує своє існування в діалозі з іншими культурами, можливому завдяки перекладу як культурологічному явищу і перекладачеві як експерту з прочитання складної системи смислів і значень вихідної культури і культури перекладу.

Висновки та перспективи подальших досліджень. Розглянувши питання тлумачення і визначення поняття культури в перекладознавстві, можна зробити такі висновки: у перекладознавстві не існує єдності щодо визначення поняття культури. Поширена в німецькомовних перекладознавчих дослідженнях дефініція культури Г. Гьорінга орієнтована насамперед на поведінкові структури та очікування суспільства і тому, на нашу думку, не завжди здатна слугувати науково-методичним і дидактичним підгрунтям перекладацької діяльності в ситуації відтворення культурно-специфічної інформації. Окрім необхідності диференційованого визначення поняття культури на рівні теоретичному, постає потреба його операціоналізації на рівні емпіричному, тобто вироблення на його основі комплексу практичних процедур, конкретних практичних кроків дій перекладача щодо сприйняття і відтворення культурної інформації. Актуальним залишається питання відбиття культури в художньому тексті та системного опису цього феномену. Системного підходу потребує також питання відтворення культурної інформації в тексті перекладу. 


\section{СПИСОК ВИКОРИСТАНОЇ ЛІТЕРАТУРИ}

1. Альошина М. Методологія “культурного повороту” в сучасному перекладознавстві і проблеми адекватності в перекладі. Фаховий та художній переклад: теорія, методологія, практика. 2014. C. 17-21. URL: https://elibrary.kubg.edu.ua/id/ eprint/22028/1/M_Aloshyna_Mkonf_4_04_2014_IF.pdf.

2. Барт Р. Избранные работы: Семиотика. Поэтика. Москва, 1989. 616 с.

3. Бахтин М. М. Литературно-критические статьи. Москва, 1986. 543 с.

4. Зорівчак Р. Український художній переклад як націєтворчий чинник. Зарубіжна лimepamypa. 2007. № 14. С. 1-5.

5. Кузенко Г. М. Культурологічний аспект перекладу у міжмовній комунікації. Міжнародний науковий журнал “Інтернаука”. 2017. № 2(2). C. 22-26. URL: http:// nbuv.gov.ua/UJRN/mnj_2017_2(2)_6.

6. Лотман Ю. М. Семіотика культури й поняття тексту: вибрані статті. Таллінн : Олександра, 1992. Т. 1. С. 129-132.

7. Олійник Т. С. Поняття “культура" у сучасному перекладознавстві. Наукові записки Національного університету “Острозька академія”. Серія: Філологічна. 2014. Вип. 45. С. 292-295. URL: http://nbuv.gov.ua/UJRN/Nznuoaf 20144587.

8. Тимко Н.В. Фактор “культура” в переводе. Курск, 2007. UR $\bar{L}$ : https://mgimo.ru/upload/ iblock/5e8/faktor-kultura-v-perevode.pdf.

9. Albrecht J. Kultur und Kulturwissenschaft. Ihre Bedeutung für die Translationswissenschaft und für die Translationspraxis. Lavinia Heller (Hg.). Kultur und Übersetzung. Studien zu einem begrifflichen Verhältnis. Bielefeld, 2017. S. 65-91.

10. Bachmann-Medick D. Cultural Turns: Neuorientierungen in den Kulturwissenschaften. Reinbek bei Hamburg, 2009. 420 S.

11. Dengscherz S. Kampf der Kulturbegriffe? Eine Fallstudie zum wissenschaftlichen Schreiben über "Kultur" im BA-Studium "Transkulturelle Kommunikation". HERMES - Journal of Language and Communication in Business. 2018. Vol. 58. S. 231-256.

12. Floros G. Kulturelle Konstellationen in Texten. Zur Beschreibung und Übersetzung von Kultur in Texten. Tübingen : Narr Verlag, 2003. 234 S.

13. Göhring H. Interkulturelle Kommunikation. Snell-Hornby et al. (Hrsg). Handbuch Translation. 2. Aufl. Tübingen : Stauffenburg, 2006. S. 112-115.

14. Koller W. Einführung in die Übersetzungswissenschaft. 6. aktualisierte Auflage. Wiebelsheim : Quelle und Meier, 2001.343 S.

15. Mudersbach K. Kultur braucht Übersetzung. Übersetzung braucht Kultur. (Modell und Methode). Thome G., Giehl C., Gerzymisch-Arbogast H. (Hrsg.). Kultur und Übersetzung. Methodologische Probleme des Kulturtransfers. Tübingen : Narr, 2002. S. 169-225.

16. Reiß K., Vermeer H. J. Grundlegung einer allgemeinen Translationstheorie. Tübingen : M. Niemeyer, 1984. 334 S.

17. Snell-Hornby M. Translation Studies. An Integrated Approach. Amsterdam [u.a.] : Benjamins, 1988. $170 \mathrm{pp}$.

18. Vermeer H. J. Übersetzen als kultureller Transfer. Snell-Hornby M. (Hrsg.) Übersetzungswissenschaft: Eine Neuorientierung. Tübingen : Francke, 1986. S. 30-53.

\section{REFERENCES}

1. Alioshyna M. Metodologiya "kuljturnogo povorotu" v suchasnomu perekladoznavstvi i problema adekvatnosti v perekladi [Methodology of "cultural turn" in modern Translation 
Studies and problems of adequacy in translation]. Fakhovyi ta khudozhniy pereklad: teoriya, metodologiya, praktyka. 2014. S. 17-21. URL: https://elibrary.kubg.edu.ua/id/ eprint/22028/1/M_Aloshyna_Mkonf_4_04_2014_IF.pdf

2. Barthes R. Izbrannye raboty: Semiotika. Poetika [Selected Works: Semiotics. Poetics]. Moskva, 1989. $616 \mathrm{~s}$.

3. Bakhtin M. M. Literaturno-kriticheskiye stati [Literary Critical Articles]. Moskva, 1986. $543 \mathrm{~s}$.

4. Zorivchak R. Ukrayinskyi khudozhniy pereklad yak naciyetvorchyj chynnyk [Ukrainian Literary Translation as a Nation-building Factor]. Zarubizhna literatura. 2007. № 14. S. 1-5.

5. Kuzenko Gh. M. Kulturologhichnyj aspect perekladu u mizhmovniy komunikaciyi [Cultural aspects of translation in Cross-language communication]. Mizhnarodnyj naukovyj zhurnal “Internauka”. 2017. № 2(2). S. 22-26. URL: http://nbuv.gov.ua/UJRN/mnj_2017_2(2)_6.

6. Lotman Yu. M. Semiotika kultury i poniattia tekstu: vybrani statti [Semiotics of Cülture and the Concept of text: Selected Articles]. Tallinn : Oleksandra, 1992. T. 1. S. 129-132.

7. Oliynyk T. S. Poniattia "kultura" u suchasnomu perekladoznavstvi [The concept of "culture" in modern translation studies]. Naukovi zapysky Natsionalnoho universytetu "Ostrozka akademiya”. Seriya: Filologichna. 2014. Vyp. 45. S. 292-295. URL: http://nbuv.gov.ua/ UJRN/Nznuoaf_2014_45_87.

8. Timko N.V. Faktor "kütura" v perevode [The "culture" factor in translation]. Kursk, 2007. URL: https://mgimo.ru/upload/iblock/5e8/faktor-kultura-v-perevode.pdf.

9. Albrecht J. Kultur und Kulturwissenschaft. Ihre Bedeutung für die Translationswissenschaft und für die Translationspraxis. Lavinia Heller (Hg.). Kultur und Übersetzung. Studien zu einem begrifflichen Verhältnis. Bielefeld, 2017. S. 65-91.

10. Bachmann-Medick D. Cultural Turns: Neuorientierungen in den Kulturwissenschaften. Reinbek bei Hamburg, 2009. 420 S.

11. Dengscherz S. Kampf der Kulturbegriffe? Eine Fallstudie zum wissenschaftlichen Schreiben über "Kultur" im BA-Studium "Transkulturelle Kommunikation". HERMES - Journal of Language and Communication in Business. 2018. Vol. 58. S. 231-256.

12. Floros G. Kulturelle Konstellationen in Texten. Zur Beschreibung und Übersetzung von Kultur in Texten. Tübingen : Narr Verlag, 2003. 234 S.

13. Göhring H. Interkulturelle Kommunikation. Snell-Hornby et al. (Hrsg). Handbuch Translation. 2. Aufl. Tübingen : Stauffenburg, 2006. S. 112-115.

14. Koller W. Einführung in die Übersetzungswissenschaft. 6. aktualisierte Auflage. Wiebelsheim : Quelle und Meier, 2001. 343 S.

15. Mudersbach K. Kultur braucht Übersetzung. Übersetzung braucht Kultur. (Modell und Methode). Thome G., Giehl C., Gerzymisch-Arbogast H. (Hrsg.). Kultur und Übersetzung: Methodologische Probleme des Kulturtransfers. Tübingen : Narr, 2002. S. 169-225.

16. Reiß K., Vermeer H. J. Grundlegung einer allgemeinen Translationstheorie. Tübingen : M. Niemeyer, 1984. 334 S.

17. Snell-Hornby M. Translation Studies. An Integrated Approach. Amsterdam [u.a.] : Benjamins, 1988. $170 \mathrm{pp}$.

18. Vermeer H. J. Übersetzen als kultureller Transfer. Snell-Hornby M. (Hrsg.) Übersetzungswissenschaft: Eine Neuorientierung. Tübingen : Francke, 1986. S. 30-53. 


\title{
THE CONCEPT OF CULTURE IN TRANSLATION AND TRANSLATION STUDIES: DESIGNING AN APPROACH TO THE DEFINITION
}

\author{
Tetiana Liashenko
}

\author{
Ivan Franko National University in Lviv, \\ 1, Universytetska Str., Lviv, 79000, Ukraine \\ laschenko_t@yahoo.de
}

In the paper, we offer the translatological definition of the concept of culture, relevant for literary translation as a culturological phenomenon. We believe that the given definition combines the main aspects of its interpretation in culturology, socio-cultural anthropology, and intercultural communication. Such an approach allows outlining cultural background knowledge of the translator, which is necessary, on the one hand, for understanding of the text and, on the other, for the adequate translation of cultural information. The article analyses various theories of the understanding of culture and the tradition of its research in the translation studies, particularly in German translatology. The combination of interpretive, linguistic and translational turns in the cultural sciences is identified as a perspective for translation studies. The attention focuses on the advantages and disadvantages of common interpretations. The paper considers the issues of meaningful and spatial definition of the concept of culture. The study characterizes the understanding of culture in the process of intercultural communication and the role of literary translation in it as well as clarifies the peculiarities of the reflection of culture in the literary text. The elements of culture that constitute translation problems are both extralinguistic concepts, i. e. phenomena and events that take place in a particular linguocultural community (the culture described by language), and "culturally conditioned" units of language as markers of a particular culture (the culture in language). In this research, we exemplify the possible ways of solving the problem of identification and translation of cultural information in literary translation. It is important to complete a systematic description of culture in literary texts to enable its identification at the macro- and microstructural levels. The article points out the need to consider the issue of identification and translation of cultural information not only at the stage of implementation of the message in the language of translation, but also at the stages of decoding the source text and its recoding. The prospects for further research are outlined, which consist in the operationalization of the concept of culture at the empirical level, a systematic description of cultural manifestations in the source text, and a systematic approach to the reproduction of cultural information in the translated text.

Key words: culture, translation studies, intercultural communication, literary translation, literary text. 